\title{
Carbon Assimilation by Claviceps purpurea Growing as a Parasite
}

\author{
By A. G. DICKERSON, P. G. MANTLE AND L. J. NISBET* \\ Department of Biochemistry, Imperial College, London $\mathrm{SW}_{7}$
}

(Received 5 March 1976; revised 23 June 1976)

\begin{abstract}
SUMMARY
Carbon assimilation by Claviceps purpurea, growing as a parasite on cereals, has been investigated by supplying the host plant with ${ }^{14} \mathrm{CO}_{2}$ in a closed system. The presence of the pathogen induced the plant to exude photosynthate which contained high levels of sucrose. During the period of ${ }^{14} \mathrm{CO}_{2}$ supply, ${ }^{14} \mathrm{C}$ was incorporated into the sucrose and so the path of carbon into the parasite could be traced. Hexoses, derived by the action of the fungal sucrase on sucrose, were assimilated by the pathogen and largely converted into polyols - mainly mannitol and, to a lesser extent, trehalose. The rate of carbohydrate metabolism decreased with maturation of the ergot, and also showed qualitative differences between the basal and apical regions of the ergot which were probably a function of nutrient supply.
\end{abstract}

\section{INTRODUCTION}

Enzymological evidence and honeydew analysis strongly suggest that growth of Claviceps purpurea during parasitism of rye or wheat ovaries is supported by sucrose released by the host as a phloem exudate (Dickerson, 1972). The supply of sucrose is maintained throughout the development of the parasite (Corbett, Dickerson \& Mantle, 1974) and the conversion of the sucrose to other carbohydrates is a feature of the constitutive enzyme activities observed in the fungal tissues and is not a function of the host.

Our aim was to establish these conclusions independently by supplying ${ }^{14} \mathrm{CO}_{2}$ to those photosynthetic tissues of the infected host plant which contribute carbon most directly to the pathogen.

\section{METHODS}

Origin of C. purpurea strain. Strain 29/4, reselected (Nisbet, 1975) from strain 17-3 as used by Corbett et al. (1974), was used. The strain was highly infectious, yielding ergots between $\mathrm{I} 5$ and $20 \mathrm{~mm}$ long and $\mathrm{I}$ and $3 \mathrm{~mm}$ wide, and also grew well in liquid culture.

Growth of host plants. Seeds of Svalof's Fourex Rye (Swedish Seed Association, Svalof, Sweden) and Maris Dove wheat (Plant Breeding Institute, Cambridge) were grown under glasshouse conditions in pots (ro per pot) and in rows in open plots at the Chelsea Physic Garden, London. Plants from the open plots were transferred to pots Io to I4 days before experiments.

Inoculation of host plants. This was normally carried out in early June before anthesis. For any single experiment, plants of the same age were all inoculated at the same time. Producof the inoculum and inoculating procedure were as described by Corbett et al. (1974).

Supply of ${ }^{14} \mathrm{CO}_{2}$ to infected plants. Figure I shows the apparatus used to supply ${ }^{14} \mathrm{CO}_{2}$ to plants. The gas was generated by injecting I $\mathrm{ml} 90 \%(\mathrm{w} / \mathrm{v})$ lactic acid through a Suba-Seal

* Present address: Roche Products Ltd, Welwyn Garden City, Hertfordshire AL7 3AY. 


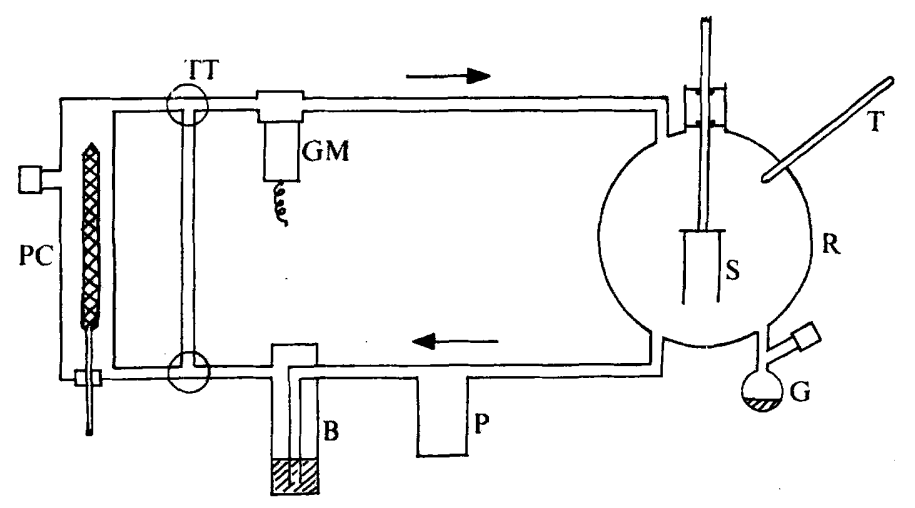

Fig. I. Apparatus for supplying ${ }^{14} \mathrm{CO}_{2}$ to plants parasitized by Claviceps purpurea. B, bubbler; G, gas generator; GM, Geiger-Müller tube; P, pump; PC, plant chamber; $R$, reservoir; $S$, stirrer; $T$, thermometer; TT, three-way tap. The arrows show the direction of gas flow. For further details, see Methods.

cap on to 15 to $20 \mathrm{mg} \mathrm{Ba}^{14} \mathrm{CO}_{3}$ and heating the mixture gently (Dickerson \& Edelman, I966). The liberated $\mathrm{CO}_{2}$ was mixed in the glass gas reservoir by an impeller, operating at $2000 \mathrm{rev}$. $\mathrm{min}^{-1}$, which had two $2 \mathrm{~cm}$ wide 'swing-out' paddles and was sealed into the reservoir with O-rings. The 51 reservoir used for most experiments represented about $90 \%$ of the volume of the entire apparatus; the initial concentration of $\mathrm{CO}_{2}$ was, therefore, about $0.08 \%$ by volume (i.e. about $2 \cdot 4$ times the background concentration). This level of $\mathrm{CO}_{2}$ was considered to be insufficient to cause aberrant metabolism of either host or parasite. Normally $500 \mu \mathrm{Ci}$ ${ }^{14} \mathrm{CO}_{2}$ was used per experiment. The gas mixture was circulated through the apparatus, excluding the plant chamber, until equilibrium, i.e. a constant reading on the rate-meter attached to the Geiger-Müller tube, was reached (normally after Io to $15 \mathrm{~min}$ at a pumping rate of $1.51 \mathrm{~min}^{-1}$ at a pressure of $0.30 \mathrm{~kg} \mathrm{~cm}^{-2}$ ). Attached inflorescences ('ears'; about 8) were washed with water (except when 'stale' honeydew was being investigated) and sealed into a perspex plant chamber of rectangular section which was illuminated bilaterally using a daylight source of approximate intensity $\mathrm{I} \times 10^{5} \mathrm{lux}(\mathrm{Philips} \mathrm{MBRF} / \mathrm{U} ; 700 \mathrm{~W}$ ) on one side of the chamber and a mirror on the other. Gas was then circulated through the plant chamber. Honeydew from infected florets was sampled using a hypodermic needle pushed through the Suba-Seal cap on the port in the plant chamber.

Excised inflorescences with their stems in water were supplied with ${ }^{14} \mathrm{CO}_{2}$ in a modified apparatus in which the plant chamber was round in section and permitted the use of up to 25 ears. Undue misting was prevented by an additional impeller directly beneath the water vessel containing the ears. This horizontal fan impeller with a magnetic flea in the base of the spindle had sixteen $\mathrm{I} \mathrm{cm}$ wide blades. The base of the plant chamber was sealed with a greased glass plate and placed on a magnetic stirrer to rotate the impeller.

The internal temperature of the apparatus did not rise above $30^{\circ} \mathrm{C}$ in any experiment.

Honeydew collection. Honeydew appeared on the florets about Io days after inoculation of the plant and was collected at intervals with a hypodermic syringe. Freshly exuded honeydew was obtained by washing plants free from old honeydew and collecting the subsequent exudate. Spores were removed by centrifuging the honeydew which in some cases was dialysed overnight at $4{ }^{\circ} \mathrm{C}$ against at least 2000 vols $0.05 \mathrm{M}$-sodium phosphate buffer pH 6.8. The dialysed material was either used immediately or freeze-dried.

Sampling and extraction of ergots. At intervals during ${ }^{14} \mathrm{CO}_{2}$ feeding, the plant chamber 
was isolated by the three-way taps, and some ears were removed from the chamber, washed briefly in distilled water and dropped into liquid nitrogen. The chamber was then resealed and ${ }^{14} \mathrm{CO}_{2}$ supply was continued. Uninfected ovaries and developing ergots were dissected from frozen ears and extracted separately for acid-soluble material and soluble carbohydrates by the methods described by Corbett et al. (1974). Occasionally, tissues were not extracted directly but were blended for I min in a small volume of water (approximately twice the wet weight of the tissues) in a vortex mixer. The resultant slurry was freeze-dried and the residue was stored at $-20^{\circ} \mathrm{C}$ under vacuum. For analysis of non-polar materials (i.e. carbohydrates), residues were reconstituted in water and deionized as previously described (Dickerson \& Mawer, 1974).

Because of the difficulty of precisely standardizing plants and experimental conditions, absolute levels of compounds investigated and the levels of ${ }^{14} \mathrm{C}$ incorporated into the parasite varied by up to $30 \%$ between experiments. However, variations of the ratio of incorporation of ${ }^{14} \mathrm{C}$ into the individual metabolites assayed did not exceed $10 \%$. The results presented are for experiments where relatively large amounts of fungal tissue were available, thus enabling the most accurate determinations of specific radioactivity to be carried out.

Incubation of ergots. Ergots ( 2 to 4-weeks-old; from strain 29/4 growing on wheat) and sections of ergots were briefly washed in sterile 2 mM-sodium phosphate buffer pH 6.8. Normally tissue ( 300 to $400 \mathrm{mg} \mathrm{ml}^{-1}$ ) was then incubated in the same buffer containing $15 \%$ $(\mathrm{w} / \mathrm{v})\left[\mathrm{U}-{ }^{14} \mathrm{C}\right]$ sucrose or $\left[\mathrm{U}-{ }^{14} \mathrm{C}\right]$ glucose $(2$ to $20 \mu \mathrm{Ci})$. Incubation was carried out in a lightly-stoppered, shaken tube maintained at $25^{\circ} \mathrm{C}$. At intervals, samples (Io to $20 \mu$ l) were removed from the incubation medium for analysis. Results are given as the mean of three replicates; the overall variation did not exceed $10 \%$.

Extraction of enzymes from whole ergots. Ergots grown on wheat in the glasshouse were harvested 4 weeks after inoculation and suspended overnight at $25^{\circ} \mathrm{C}$ in 2 mM-sodium phosphate buffer pH 6.8 (40 $\mathrm{g}$ fresh wt/100 ml buffer). They were then extracted for $5 \mathrm{~h}$ at $25^{\circ} \mathrm{C}$ by grinding with glass in a pestle and mortar. The resultant slurry was cooled in ice for $\mathrm{I} \mathrm{h}$ and centrifuged at $4{ }^{\circ} \mathrm{C}$ and $17000 \mathrm{~g}$ for $30 \mathrm{~min}$. The supernatant was freeze-dried and yielded $5 . \mathrm{I} \mathrm{g}$ residue which was stored under vacuum at $-20^{\circ} \mathrm{C}$. Before incubation, the freeze-dried residue was reconstituted in $50 \mathrm{~mm}$-sodium phosphate buffer $\mathrm{pH} 6.8$, and dialysed overnight at $4{ }^{\circ} \mathrm{C}$ against the same buffer. The soluble protein concentration of the dialysed solution, measured at $280 \mathrm{~nm}$ after clearing by centrifuging at $20000 \mathrm{~g}$, indicated that the freeze-dried residue contained II \% (w/w) protein.

Enzyme incubation. [U-14 C]glucose $(0 \cdot \mathrm{I} \mathrm{M})$ and $\left[\mathrm{U}-{ }^{14} \mathrm{C}\right]$ sucrose $(0 \cdot 044 \mathrm{M})$ were incubated at $25{ }^{\circ} \mathrm{C}$ with the above enzyme extract; the final concentration of soluble protein in the incubation mixture was $0.26 \mathrm{mg} \mathrm{ml}^{-1}$. For polyol synthesis, the incubation mixture also contained $0.02 \mathrm{M}-\mathrm{NADPH}, 0.0 \mathrm{I} \mathrm{M}-\mathrm{ATP}$ and $0.02 \mathrm{M}-\mathrm{MgCl}_{2} .6 \mathrm{H}_{2} \mathrm{O}$. Samples were removed for analysis at intervals over a period of $5 \mathrm{~h}$. Results are given as the mean of three replicates; the overall variation did not exceed $5 \%$.

Carbohydrate estimation. Carbohydrates were identified and estimated as described previously (Corbett, Dickerson \& Mantle, 1974, 1975).

Chromatography. The methods used were essentially those described by Corbett et al. (1974, 1975). Estimations by gas-liquid chromatography were carried out on a Pye 104 chromatograph with a $3 \%$ SE 52 column programmed at $130^{\circ} \mathrm{C}$ for $4 \mathrm{~min}$, then rising by $6{ }^{\circ} \mathrm{C}$ $\mathrm{min}^{-1}$ to $250^{\circ} \mathrm{C}$ and a final run of $15 \mathrm{~min}$ isothermally. Silyl derivatives of carbohydrates were prepared as before and identification was carried out by reference to markers using both retention time and temperature of emergence from the column.

Assay of radioactivity. This was carried out as described by Corbett et al. (1975) using a 


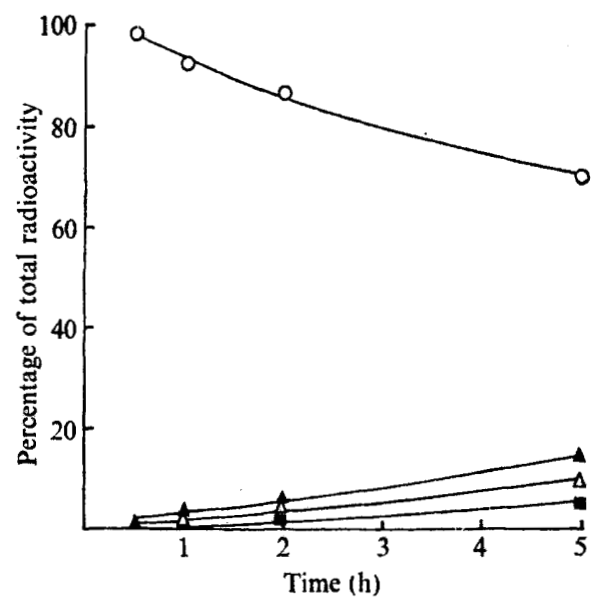

Fig. 2. Levels of ${ }^{14} \mathrm{C}$ in sugars in honeydew exuded by rye plants, parasitized by Claviceps purpurea, during a period of ${ }^{14} \mathrm{CO}_{2}$ supply to the plant. Sugars in the honeydew were separated by chromatography and assayed for radioactivity. The radioactivity in individual sugars in each sample is expressed as a percentage of the total radioactivity for all the sugars determined for that sample. $O$, Sucrose; $\Delta$, fructose; $\Delta$, glucose; $\boldsymbol{m}$, oligosaccharides.

Beckman LS $200 B$ counter. In the apparatus used to supply ${ }^{14} \mathrm{CO}_{2}$ to plants, radioactivity was monitored with a model E Mini-instruments monitor (type 5.I0); the Geiger-Müller tube (Mullard MX 123) was modified so that only the face of the tube was enclosed in the apparatus. The efficiency of the tube when the apparatus contained $0.5 \mathrm{mCi}$ of thoroughly mixed gas was $2 \%$ and, as the efficiency did not exceed $3 \%$ even at low isotope levels, radioactivities are recorded without correction.

\section{RESULTS}

In a typical experiment over $90 \%$ of the $\mathrm{CO}_{2}$ supplied to infected ears had been assimilated after $5 \mathrm{~h}$. Monitoring showed that nearly all the ${ }^{14} \mathrm{C}$ supplied was retained in the ear. Rates of assimilation were the same irrespective of whether ears were still attached to the plant or isolated standing in water; metabolism (see below) with respect to both host and parasite was also similar. Evans et al. (1972) found that if $\mathrm{CO}_{2}$ was supplied to the flag leaf of the plant alone, instead of the ears, only a small proportion of the ${ }^{14} \mathrm{C}$ appeared in the ear; in our experiments, the amount of ${ }^{14} \mathrm{C}$ translocated to the ears was less than $10 \%$ of that supplied to the flag leaf.

Directly after a period (normally $5 \mathrm{~h}$ ) of ${ }^{14} \mathrm{CO}_{2}$ feeding, the level of ${ }^{14} \mathrm{C}$ in the developing ergot was found to be between 4 and 17 times higher (on a tissue freeze-dried weight basis) than that in the uninfected, developing seeds in the same ear. The difference tended to be lower as the ergot approached maturity. Considerable variation also occurred depending on the relative positions of the parasite and developing seed within the ear. Dissemination of ${ }^{14} \mathrm{C}$ into metabolites was greater in the fungal tissues which showed high levels in many compounds after $5 \mathrm{~h}$. In contrast, in most of the uninfected seeds $90 \%$ or more of the ${ }^{14} \mathrm{C}$ was in sucrose.

Samples of honeydew that exuded from the ears during $\mathrm{CO}_{2}$ assimilation were removed at intervals and the sugars in the exudate were assayed for radioactivity. Sucrose was the first 
Table I. Specific activity of carbohydrates in honeydew removed from the inflorescence of rye during a period of ${ }^{14} \mathrm{CO}_{2}$ supply

\begin{tabular}{|c|c|c|c|c|}
\hline \multirow[b]{2}{*}{ Carbohydrate } & \multicolumn{2}{|c|}{ Fresh* honeydew } & \multicolumn{2}{|c|}{ Stale $†$ honeydew } \\
\hline & $\begin{array}{c}\text { Concn } \\
\left(\mathrm{mg} \mathrm{ml}^{-1}\right)\end{array}$ & $\begin{array}{l}\text { Specific radioactivity } \\
\text { at } \mathrm{I} h\left(\mu \mathrm{Ci} \mathrm{mg}^{-1}\right)\end{array}$ & $\begin{array}{c}\text { Concn } \\
\left(\mathrm{mg} \mathrm{ml}^{-1}\right)\end{array}$ & $\begin{array}{l}\text { Specific radioactivity } \\
\text { at } \mathrm{I} h\left(\mu \mathrm{Ci} \mathrm{mg}^{-1}\right)\end{array}$ \\
\hline $\begin{array}{l}\text { Fructose } \\
\text { Glucose }\end{array}$ & $\begin{array}{l}50 \\
26\end{array}$ & $\begin{array}{l}0.05 \\
0.14\end{array}$ & $\begin{array}{l}486 \\
278\end{array}$ & $\begin{array}{l}0.008 \\
0.022\end{array}$ \\
\hline Sucrose & 380 & 0.25 & 3 & $29 \cdot 3$ \\
\hline Oligosaccharides & 一 & - & I.5 & $1 \cdot 3$ \\
\hline
\end{tabular}

* Freshly exuded honeydew; equivalent to honeydew at its first appearance on the floret following infection, i.e. 10 to II days.

$\uparrow$ Honeydew equivalent to that found 6 days after its first appearance, i.e. 16 to 17 days after infection.

compound to become labelled (Fig. 2). Glucose, fructose and oligosaccharides subsequently became labelled in a manner consistent with their formation by the action of the fungal sucrase. The structures of the oligosaccharides were the same as those reported previously for C. purpurea (Dickerson, 1972 ).

Freshly exuded honeydew, especially material that had only been in brief contact with the infected ovary and was uncontaminated with fungal spores, contained up to $40 \%$ (w/v) of free sugar, mostly ( 90 to $100 \%$ ) sucrose (see below). The specific radioactivities of the various sugars in honeydew collected when ${ }^{14} \mathrm{CO}_{2}$ was being assimilated were more similar than those in staler honeydew. The staler honeydew occurred on ears that were not washed before supplying ${ }^{14} \mathrm{CO}_{2}$ and thus were contaminated with sphacelial conidia and had been in contact with mycelia. Consequently, sucrase activity of the fungal tissues led to higher proportions of monosaccharide and a relatively lower sucrose content (Table I).

At intervals during and after supplying the plants with ${ }^{14} \mathrm{CO}_{2}$, three or four infected ears were removed from the apparatus, and the ergots were dissected out, divided transversely into three equal portions and extracted. Soluble sugars and polyols in the deionized extracts were assayed and their ${ }^{14} \mathrm{C}$ levels were determined (Table 2). Even if all the $\mathrm{CO}_{2}$ assimilated during a single experiment was converted to carbohydrate, the total carbohydrate level in all the ears together would be no more than about $3 \mathrm{mg}$ higher. Therefore the differences in the weights of the carbohydrates observed at any one sampling time were due to the normal distribution within the ergot.

On the I8th day after inoculation, mannitol, fructose and trehalose showed the highest levels in the ergots. Mannitol was fairly uniformly distributed, fructose accumulated towards the apex and trehalose towards the base of the ergot. Glucose showed apical accumulation but arabinitol and sucrose were uniformly distributed. At the 25th day after inoculation, ergots showed fairly high levels of mannitol and trehalose, both of which accumulated towards the base. In these ergots, other sugars and arabinitol were uniformly low.

The increases in the specific radioactivities of the sugars were always greatest towards the base of the ergot. The younger ergots showed the greatest increases. In most cases, the specific activities of glucose, fructose and mannitol were similar at $\mathrm{I} h$ but by $5 \mathrm{~h}$ that of mannitol was substantially greater than the others. The high specific activity of sucrose in a few ergots was possibly due to some sucrose being carried over on the outside of the ergot despite washing before extraction.

When isolated ergots bisected transversely were incubated in media containing $15 \%(\mathrm{w} / \mathrm{v})$ sucrose (this level was used as it is frequently found in the parasitic condition in honeydew), 
Table 2. Incorporation of ${ }^{14} \mathrm{C}$ into various carbohydrates of ergots following supply of ${ }^{14} \mathrm{CO}_{2}$ to the plant they were parasitizing

Ergots were divided transversely into three equal portions; soluble sugars and polyols in extracts of these portions were assayed and the ${ }^{14} \mathrm{C}$ contents were determined (see Methods).

\begin{tabular}{|c|c|c|}
\hline \multicolumn{3}{|c|}{ Top segment } \\
\hline $\begin{array}{c}10^{2} \times \\
{ }^{14} \mathrm{C}^{2} \text { content } \\
\left(\mu \mathrm{Ci}^{*}\right)\end{array}$ & $\begin{array}{l}\text { Concn } \\
\left(\mathrm{mg}^{*}\right)\end{array}$ & 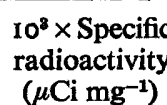 \\
\hline
\end{tabular}

\begin{tabular}{|c|c|c|}
\hline \multicolumn{3}{|c|}{ Middle segment } \\
\hline $\begin{array}{c}10^{2} \times \\
{ }^{14} \mathrm{C} \text { content } \\
\left(\mu \mathrm{Ci}^{*}\right)\end{array}$ & $\begin{array}{c}\text { Concn } \\
\text { (mg*) }\end{array}$ & 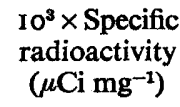 \\
\hline
\end{tabular}

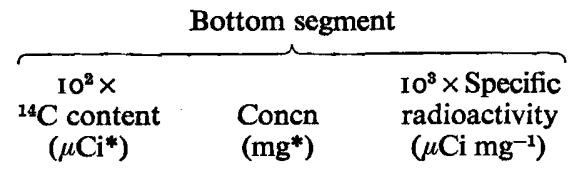

Ergots analysed 18 days after inoculation of plants

I h sample

Arabinitol

Mannitol

Fructose

Glucose

Sucrose

Trehalose

5 h sample

Arabinitol

Mannitol

Fructose

Glucose

Sucrose

Trehalose

0.6
3.2
0.5
0.7
0.8
$1 \cdot 4$

0.1
44.9
$3 \cdot 3$
3.7
0.7
17.8

0.8
$15 \cdot 3$
$16 \cdot 6$
$2 \cdot 7$
0.5
$3 \cdot 2$

0.9
$10 \cdot 7$
$13 \cdot 8$
$3 \cdot 2$
0.4
$3 \cdot 2$

Ergots analysed 25 days after inoculation of plants

I h sample

Arabinitol

Mannitol

Fructose

Glucose

Sucrose

5 h sample

Arabinitol

Mannitol

Fructose

Glucose

Sucrose

Trehalose

$\begin{array}{ll}0.1 & 0.3 \\ 0.9 & 2.9 \\ 0.2 & 1.2 \\ 0.1 & 0.6 \\ 0.4 & 0.3 \\ 6.6 & 5.4 \\ & \\ 0.03 & 0.2 \\ 0.8 & 1.8 \\ 0.5 & 1.6 \\ 0.6 & 0.4 \\ 0.4 & 0.2 \\ 0.4 & 3.1\end{array}$

$\begin{array}{rr}0.2 & 0.6 \\ 22 \cdot 3 & 7 \cdot 9 \\ 4.7 & 1 \cdot 9 \\ 2.4 & 1 \cdot 0 \\ 0.8 & 0.3 \\ 7 \cdot 2 & 10 \cdot 0 \\ & \\ 1 \cdot 0 & 0.8 \\ 298 \cdot 3 & 7 \cdot 7 \\ 20.3 & 2 \cdot 0 \\ 6.4 & 0.9 \\ 2.8 & 0.3 \\ 79.4 & 12.8\end{array}$

$3 \cdot 0$
$28 \cdot 0$
$25 \cdot 0$
$24 \cdot 0$
$23 \cdot 1$
$7 \cdot 2$

$12 \cdot 0$
$387 \cdot 0$
$102 \cdot 0$
$71 \cdot 0$
$98 \cdot 1$
$61 \cdot 9$

$4 \cdot 1$
$203 \cdot 4$
$46 \cdot 9$
$24 \cdot 4$
$4 \cdot 9$
$70 \cdot 4$

$12 \cdot 8$
$2148 \cdot 6$
$170 \cdot 2$
$64 \cdot 4$
$16 \cdot 5$
$741 \cdot 7$

(mg*) $\left(\mu \mathrm{Ci} \mathrm{\textrm {mg } ^ { - 1 } )}\right.$

$\begin{array}{rr}7 \cdot I & 0 \cdot 2 \\ 2 \cdot I & 22 \cdot 3 \\ 3 \cdot I & 4 \cdot 7 \\ 2 \cdot 4 & 2 \cdot 4 \\ 16 \cdot 7 & 0 \cdot 8 \\ 4 \cdot 3 & 7 \cdot 2 \\ & \\ I \cdot 3 & I \cdot 0 \\ 42 \cdot 0 & 298 \cdot 3 \\ 2 \cdot 4 & 20 \cdot 3 \\ 12 \cdot 0 & 6 \cdot 4 \\ 16 \cdot 6 & 2 \cdot 8 \\ 55 \cdot 2 & 79 \cdot 4\end{array}$

$12 \cdot 8$

$6 \mathrm{I} \cdot 9$

$45 \cdot 0$
$145 \cdot 0$
$223 \cdot 0$
$203 \cdot 0$
$153 \cdot 0$
$59 \cdot 3$

$213 \cdot 0$
$1653 \cdot 0$
$851 \cdot 0$
$586 \cdot 0$
$381 \cdot 0$
$466 \cdot 0$

$3 \cdot 3$
$3 \cdot 1$
$1 \cdot 5$
$1 \cdot 4$
$11 \cdot 5$

$\begin{array}{cl}0.1 & 0.8 \\ 1.6 & 5.9 \\ 0.4 & 1.2 \\ 0.2 & 0.3 \\ 0.5 & 0.04 \\ I .6 & 9.7 \\ & \\ 0.04 & 0.7 \\ 20.5 & 4.5 \\ 0.9 & 1.0 \\ 0.3 & 0.3 \\ 0.6 & 0.1 \\ 3.2 & 9.5\end{array}$

$0 \cdot 9$
$2 \cdot 7$
$3 \cdot 4$
$5 \cdot 0$
$140 \cdot 0$
$1 \cdot 7$

$0 \cdot 6$
$46 \cdot 0$
$9 \cdot 0$
$8 \cdot 0$
$85 \cdot 7$
$3 \cdot 4$

* Per $100 \mathrm{mg}$ freeze-dried weight of tissue.

\begin{tabular}{|c|c|c|c|c|c|c|}
\hline$I \cdot 6$ & 0.04 & 0.7 & 0.6 & $1 \cdot 2$ & 0.2 & $60 \cdot 0$ \\
\hline $4 \cdot 6$ & $20.5^{\circ}$ & $4 \cdot 5$ & $46 \cdot 0$ & $458 \cdot 8$ & $7 \cdot 3$ & $629 \cdot 0$ \\
\hline 2.9 & 0.9 & $1 \cdot 0$ & 9.0 & $23 \cdot I$ & $1 \cdot 3$ & $178 \cdot 0$ \\
\hline $15 \cdot 0$ & 0.3 & 0.3 & 8.0 & $6 \cdot 7$ & 0.4 & 168.0 \\
\hline $24 \cdot 7$ & 0.6 & 0.1 & $85 \cdot 7$ & $2 \cdot 9$ & 0.1 & $317^{\circ} 0$ \\
\hline I. 4 & $3 \cdot 2$ & 9.5 & 3.4 & $117 \cdot 7$ & I I 3 & 104.5 \\
\hline
\end{tabular}


Table 3. Synthesis of oligosaccharides by segments of ergots

Ergots (strain $29 / 4 ; 20$-days-old) from wheat were washed in buffer (2 mm-sodium phosphate pH 6.8), bisected transversely and the apical and basal halves were incubated separately in lightlystoppered, shaken tubes at $25^{\circ} \mathrm{C}$. The incubating medium (I ml per 300 to $400 \mathrm{mg}$ tissue) contained $15 \%(\mathrm{w} / \mathrm{v})\left[\mathrm{U}-{ }^{14} \mathrm{C}\right]$ sucrose $\left(2 \mu \mathrm{Ci} \mathrm{ml}{ }^{-1}\right)$ in the same buffer. Total oligosaccharide content is expressed as a percentage of the total carbohydrates in the incubation medium as determined by ${ }^{14} \mathrm{C}$ content.

$\begin{array}{ccc}\text { Sampling } & \text { Total oligosaccharide content }(\%, w / v) \\ \text { time (h) } & \overbrace{\text { Apical half }} & \text { Basal half } \\ 0 & 0.6 & 0.5 \\ \frac{1}{2} & 2.9 & 1.6 \\ \text { I } & 5.2 & 2.8 \\ 2 & 13.2 & 5.1 \\ 5 & 25.7 & 6.6\end{array}$

Table 4. Synthesis of oligosaccharides by cell-free extracts of ergots in the presence or absence of added monosaccharides

The enzyme extract, prepared as described in Methods, was incubated in shaken tubes at $25^{\circ} \mathrm{C}$ with [U-14 C] sucrose (10 $\mu \mathrm{Ci} \mathrm{ml}^{-1}$; final concentration $0.044 \mathrm{M}$ ) in the presence or absence of a mixture of glucose and fructose both equimolar to the sucrose. Results are expressed as in Table 3 .

$\begin{array}{cccc}\begin{array}{c}\text { Sampling } \\ \text { time (min) }\end{array} & \text { Incubated with } \ldots & \overbrace{\begin{array}{c}\text { Sucrose } \\ \text { alone }\end{array}}^{\text {Total oligosaccharide content }(\%, w / v)} \\ 0 & 0.3 & \begin{array}{c}\text { Sucrose and } \\ \text { monosaccharides }\end{array} \\ 5 & 0.9 & 0.2 \\ 10 & 1 \cdot 3 & 0.8 \\ 20 & 2 \cdot 2 & 1 \cdot 1 \\ 40 & 4 \cdot 0 & 1 \cdot 7 \\ 80 & 6.5 & 2.9 \\ 120 & 8.4 & 4.7 \\ & & 6.0\end{array}$

the rate of sucrose breakdown by both the apical and basal segments was the same, $0.22 \mu$ mol $\mathrm{h}^{-1}$ (mg fresh wt tissue) $)^{-1}$. However, the oligosaccharides formed a larger proportion of the products in the top half of the ergot (Table 3). After $5 \mathrm{~h}$ both halves of the ergot had assimilated 5 to $7 \%$ of the hexose liberated, mostly as glucose (this value also includes hexose fermented during the same period; see Nisbet, 1975). Similarly, segments of ergots incubated with $15 \%(\mathrm{w} / \mathrm{v})$ glucose instead of sucrose assimilated up to $10 \%$. The assimilated hexose gave rise to mannitol in the tissues, as previously noted during stromatal incubation (Corbett et al., 1975).

When a partially-purified extract of whole ergots was incubated with $\mathrm{I} \cdot 5 \%(\mathrm{w} / \mathrm{v})$ sucrose, the levels of products were essentially the same as those obtained by incubating the basal segments of whole ergots. In the presence of a mixture containing glucose and fructose, both equimolar to the sucrose, the rate of sucrose breakdown was slightly depressed $[0.74$ to $0.85 \mu \mathrm{mol} \mathrm{min} \mathrm{m}^{-1}$ (mg protein) ${ }^{-1}$ ] and even lower levels of oligosaccharide were obtained (Table 4).

Suppression of oligosaccharide formation was also observed when honeydew, which contains some extracellular sucrase (Dickerson, 1972), was incubated with [U-14 C]sucrose (final concentration $10 \%, w / v)$. Removal of free hexose by dialysis of honeydew before addition of sucrose resulted in nearly nine times as much oligosaccharide being formed 


\section{Table 5. Action of enzymes in honeydew from rye on sucrose}

Honeydew from rye infected with $C$. purpurea (strain 29/4), collected 17 days after infection, was incubated with $10 \%(\mathrm{w} / \mathrm{v})\left[\mathrm{U}-{ }^{14} \mathrm{C}\right]$ sucrose $\left(10 \mu \mathrm{Ci} \mathrm{ml}^{-1}\right)$ at $25{ }^{\circ} \mathrm{C}$. Honeydew that had been dialysed (see Methods) was incubated under similar conditions. Results are expressed as $\mu \mathrm{mol}$ labelled product $(\mathrm{ml} \text { incubation medium })^{-1}(\mathrm{mg} \text { protein })^{-1}$ : protein concentrations of honeydew, as measured at $280 \mathrm{~nm}$, were $3.4 \mathrm{mg} \mathrm{ml}^{-1}$ before dialysis and $2.7 \mathrm{mg} \mathrm{ml}^{-1}$ after dialysis.

\begin{tabular}{|c|c|c|c|c|c|c|}
\hline \multirow{2}{*}{$\begin{array}{l}\text { Sampling } \\
\text { time (min) }\end{array}$} & \multicolumn{3}{|c|}{$\begin{array}{l}\text { Products of incubation with } \\
\text { undialysed honeydew }\end{array}$} & \multicolumn{3}{|c|}{$\begin{array}{l}\text { Products of incubation with } \\
\text { dialysed honeydew }\end{array}$} \\
\hline & Fructose & Glucose & Oligosaccharide & Fructose & Glucose & Oligosaccharide \\
\hline IO & 9.0 & $14 \cdot 2$ & $I \cdot 3$ & $7 \cdot I$ & 10.2 & 3.0 \\
\hline 20 & I 3.4 & 20.5 & $I \cdot 6$ & II $\cdot 8$ & $16 \cdot 3$ & $5 \cdot I$ \\
\hline 40 & $21 \cdot 6$ & 30.9 & $2 \cdot 4$ & 19.0 & $27 \cdot 3$ & $8 \cdot 7$ \\
\hline 80 & $36 \cdot 8$ & $46 \cdot 5$ & $3 \cdot 0$ & $24 \cdot 4$ & $41 \cdot 6$ & I3.I \\
\hline 300 & $57 \cdot \mathrm{I}$ & $65 \cdot 8$ & $3 \cdot 2$ & $60 \cdot 3$ & $85 \cdot 0$ & $27 \cdot 8$ \\
\hline
\end{tabular}

Table 6. Synthesis of mannitol by cell-free extracts of ergots

The enzyme extract, prepared as described in Methods, was incubated in shaken tubes at $25{ }^{\circ} \mathrm{C}$ with $0.1 \mathrm{M}$-[U-14 C]glucose $\left(20 \mu \mathrm{Ci} \mathrm{m}^{-1}\right), 0.02 \mathrm{M}-\mathrm{NADPH}, 0.02 \mathrm{M}-\mathrm{MgCl}_{2} .6 \mathrm{H}_{2} \mathrm{O}$ and $0.01 \mathrm{M}-\mathrm{ATP}$. Results are expressed as $\mu \mathrm{mol}$ hexose or hexose equivalent (ml incubation medium) ${ }^{-1}$.

$\begin{array}{cccc}\begin{array}{c}\text { Sampling } \\ \text { time (min) }\end{array} & \text { Glucose } & \text { Sugar phosphate } & \text { Mannitol } \\ 0 & 100 & 0 & 0 \\ 10 & 95 \cdot 7 & 3.6 & 0.6 \\ 20 & 94.3 & 4 \cdot 8 & 0.9 \\ 40 & 92 \cdot 7 & 6.0 & 1 \cdot 3 \\ 80 & 92 \cdot 0 & 6.2 & 1 \cdot 8 \\ 120 & 91 \cdot 8 & 6.0 & 2 \cdot 2 \\ 300 & 91 \cdot 5 & 5.8 & 2 \cdot 8\end{array}$

(Table 5). With honeydew collected on the first day after its appearance on the inflorescences (Table I), oligosaccharide formation was also suppressed [the corresponding $5 \mathrm{~h}$ values being 8.3 and $13.2 \mu \mathrm{mol} \mathrm{ml}^{-1}$ (mg protein) ${ }^{-1}$ for the undialysed and dialysed honeydew respectively]. Wheat honeydew gave similar results.

Incubation of the enzyme extract with $0 \cdot 1 \mathrm{M}$-glucose in the presence of NADPH, ATP and $\mathrm{Mg}^{2+}$ ions yielded mannitol and sugar phosphate. With a limiting concentration of ATP ( $0.0 \mathrm{I} \mathrm{M})$ a nearly theoretical 10\% conversion of glucose to sugar phosphate plus mannitol was approached (Table 6). When either NADPH or ATP was omitted from the incubation mixture no polyol synthesis occurred.

\section{DISCUSSION}

Infected ears of rye or wheat, when supplied with $\mathrm{CO}_{2}$ in the enclosed system, assimilated the gas down to a compensation level. Measurements of radioactivity showed that most of the carbon fixed appeared in fungal tissue rather than in uninfected developing seeds in the same ear. Directional flow of metabolites from plants specifically to fungal pathogens has been well known since the early work of Yarwood \& Jacobsen (1955) and is established for rusts, smuts and powdery mildews (Smith, Muscatine \& Lewis, 1969); it also accounts for the fact that seeds from ears of cereals infected by ergot fungi have a lower mean dry weight than those from uninfected ears (Corbett et al., 1974). 
As expected, young developing sclerotia (I8 days after inoculation of the plant) were more active metabolically than 25-day-old ergots. The basal part of the ergot appeared to be more active than the apex; but studies on isolated ergots and enzyme extracts of ergots suggest that, with respect to sucrase, this was largely a result of the host's nutrient supply being more available to the basal region. The absence of a differentiated translocation system and the plectenchymatic nature of the fungal tissue (Mantle, 1972) might impede the flow of material passing up the ergot, thus causing an accumulation around the base and a higher rate of metabolism in this area.

Carbon fixed by the plant from $\mathrm{CO}_{2}$ reaches the ergot mainly as sucrose. Sucrase (Dickerson, 1972 ; Mower \& Hancock, 1975) provides a supply of free hexose which the parasite can assimilate. Differences in the levels of oligosaccharide formed on incubating washed ergots suggest that the mode of action of the enzyme is modified by its position within the ergot. Evidence from the cell-free and honeydew incubations showed that the presence of an increased level of monosaccharide suppressed oligosaccharide formation; as most of the sucrase is cell-bound (Dickerson, 1972), its activity might be affected by the distribution of metabolites. It would appear that such metabolites need not always be carbohydrates, since only trehalose shows consistent polarization of levels within the ergot. In common with other fungi, particularly fungal pathogens of plants (Smith et al., 1969; Lewis, 1974), fixed carbonin this case in hexose - is converted within the fungal tissues to a number of products, chiefly mannitol and, to a lesser extent, trehalose. This is also similar to the 'Nostoc pattern' in lichens, symbionts which show similarities to ergot-type parasitism, reported by Richardson, Smith \& Lewis (1967). The pathway to mannitol involves phosphorylated intermediates. It is likely that the pathway would include the mediation of glucose 6-phosphate and fructose 6-phosphate as in that proposed for C. purpurea by Cooke \& Mitchell (I970).

Particularly during the later stages of the experiments in which ${ }^{14} \mathrm{CO}_{2}$ was supplied to infected plants, the specific radioactivity of mannitol usually exceeded that of the hexoses. Thus, assuming hexose is the precursor for most of the mannitol, the mannitol would need to be derived from only part of the hexose in the tissues; this hexose would have to be separated from the rest and have a higher specific activity probably arising from a greater rate of turnover. Furthermore, enrichment of the specific activity of mannitol over that of the hexose from which it is derived could be achieved by the reactions of the pentose phosphate pathway (Mitchell \& Shaw, 1968; Holligan \& Jennings, 1972), especially if there is unequal isotopic labelling of the carbon atoms of the hexose.

We thank the Science Research Council for the award of a Research Studentship to L. J. N.

\section{REFERENCES}

COOKE, R. C. \& MrTChell, D. T. (1970). Carbohydrate physiology of sclerotia of Claviceps purpurea during dormancy and germination. Transactions of the British Mycological Society 54, 93-99.

Corbett, K., Dickerson, A. G. \& MANtle, P. G. (1974). Metabolic studies on Claviceps purpurea during parasitic development on rye. Journal of General Microbiology 84, 39-58.

Corbett, K., Dickerson, A. G. \& Mantle, P. G. (1975). Metabolism of the germinating sclerotium of Claviceps purpurea. Journal of General Microbiology 90, 55-68.

Dickerson, A. G. (1972). A $\beta$-D-fructofuranosidase from Claviceps purpurea. Biochemical Journal 129, 263-272.

Dickerson, A. G. \& Edelman, J. (1966). The metabolism of fructose polymers in plants. Journal of Experimental Botany 17, 612-619.

Dickerson, A. G. \& MAWER, J. (1974). Purification of inulobiose obtained by acid hydrolysis of inulin. Carbohydrate Research 39, 162-163. 
Evans, L. T., Bingham, J., JACKson, P. \& SutherLAND, J. (1972). Effect of awns and drought on the supply of photosynthate and its distribution within wheat ears. Annals of Applied Biology 70, 67-76.

Holligan, P. M. \& JenNings, D. H. (1972). Unexpected labelling patterns from radioactive sugars fed to plants containing mannitol. Phytochemistry Ir, 3447-345I.

Lewis, D. H. (1974). Micro-organisms and plants: the evolution of parasitism and mutualism. Symposia of the Society for General Microbiology 24, 367-392.

Mantle, P. G. (1972). An unusual parasitic association between Claviceps purpurea and rye. Transactions of the British Mycological Society 59, 327-330.

Mrtchell, D. \& SHAW, M. (1968). Metabolism of glucose- ${ }^{14} \mathrm{C}$, pyruvate- ${ }^{14} \mathrm{C}$ and mannitol- ${ }^{14} \mathrm{C}$ by Melampsora lini. II. Conversion to soluble products. Canadian Journal of Botany 46, 453-460.

MOWER, R. L. \& HANCOCK, J. G. (1975). Mechanism of honeydew formation by Claviceps species. Canadian Journal of Botany 53, 2826-2834.

NisBet, L. J. (1975). Differentiation of Claviceps purpurea during parasitic and axenic culture. Ph.D. thesis, University of London.

RichaRdson, D. H. S., SMITH, D. C. \& LewIS, D. H. (1967). Carbohydrate movement between the symbionts of lichens. Nature, London 214, 879-882.

Smith, D., Muscatine, L. \& Lewis, D. (1969). Carbohydrate movement from autotrophs to heterotrophs in parasitic and mutualistic symbiosis. Biological Reviews 44, 17-90.

YARwoOD, C. E. \& JACOBSEN, L. (1955). Accumulation of chemicals in diseased areas of leaves. Phytopathology $45,43-48$. 